\title{
Effects of Intercropping with Bidens Species on Nutrient Absorption of Grape Seedlings under Cadmium Stress
}

\author{
Jiajing Huang ${ }^{1, a}$, Jianhua Li ${ }^{2, b}$, Lijin Lin ${ }^{3, c}$, Wei Jiang ${ }^{4, d}$ and Ming'an Liao ${ }^{1, e^{\star}}$ \\ ${ }^{1}$ College of Horticulture, Sichuan Agricultural University, Chengdu, Sichuan, China \\ ${ }^{2}$ Sichuan Ya'an Municipal Product Quality Supervision \& Inspection Institute, Ya'an, Sichuan, China \\ ${ }^{3}$ Institute of Pomology and Olericulture, Sichuan Agricultural University, Chengdu, Sichuan, China \\ ${ }^{4}$ College of Chemistry and Life Science, Chengdu Normal University, Chengdu, Sichuan, China \\ a2298842195@qq.com, b710753781@qq.com, cllj800924@163.com, d1399945180@qq.com, \\ elman@sicau.edu.cn
}

${ }^{*}$ Corresponding author. Jiajing Huang, Jianhua Li and Lijin Lin contributed equally to this work.

Keywords: Grape; Intercropping; Nutrient absorption; Bidens species; Cadmium stress

Abstract: To study the effects of intercropping on nutrient absorption of plants under cadmium $(\mathrm{Cd})$ stress, a pot experiment was conducted to study the effects of intercropping with four Bidens species (Bidens bipinnata, Bidens pilosa, Bidens parviflora and Bidens biternata) on the nitrogen $(\mathrm{N})$, phosphorus $(\mathrm{P})$ and potassium $(\mathrm{K})$ uptake of grape seedlings under $\mathrm{Cd}$ stress. When grape seedlings intercropped with four Bidens species, the total $\mathrm{N}$ and total $\mathrm{K}$ contents in grape seedlings decreased compared with the monoculture. Intercropping decreased the total $\mathrm{P}$ content in roots of grape seedlings except intercropping with $B$. pilosa and increased the total $\mathrm{P}$ content in shoots of grape seedlings except intercropping with $B$. parviflora. Compared with the monoculture, the soil available $\mathrm{P}$ and available $\mathrm{K}$ concentrations of intercropping decreased, but the soil alkali soluble $\mathrm{N}$ concentration of intercropping significantly increased. On the whole, intercropping with $B$. pilosa could most effectively improve the $\mathrm{P}$ absorption of grape seedlings and inhibit the $\mathrm{N}$ and $\mathrm{K}$ absorption of that. Therefore, intercropping with $B$. pilosa could benefit the nutrient absorption of grape seedlings under Cd stress.

\section{Introduction}

Intercropping as a major agricultural production model, could improve the production of composite plant population and the nutrient resources of soil [1]. Intercropping with white clover and perennial ryegrass in apple orchard improve the soil hydrolyzed nitrogen $(\mathrm{N})$, soil available phosphorus $(\mathrm{P})$ and soil available potassium $(\mathrm{K})$ concentrations [2]. Natural grass in orchard significantly improves the available N, P and $\mathrm{K}$ concentrations in soil [3]. Intercropping with soybean or peanut in orchard also significantly improve the available nutrient concentrations of different layers of soil [4]. The rhizosphere effects occur in plants when intercropping to make a series of changes of physiology and biochemistry under heavy metal stress [5]. However, there are few studies on nutrient absorption of plants by intercropping with hyperaccumulator or accumulator plants under heavy metal stress. Bidens is one of Compositae, and some studies have shown that some species of it have accumulation ability of heavy metals such as Cd [6-8], but there is no study on nutrient absorption of fruit tree intercropping with Bidens species under heavy metal stress. Therefore, in this study, four Bidens species (Bidens bipinnata, Bidens pilosa, Bidens parviflora and Bidens biternata) were used to intercrop with grape seedlings under Cd stress, and the effects of intercropping with Bidens species on nutrient uptake of grape seedlings were studied. The aim of this study was to screen out the best Bidens species which could promote the nutrient absorption of grape.

\section{Materials and Methods}

Materials. In April, 2016, the seeds of four Bidens species (B. bipinnata, B. pilosa, B. parviflora and $B$. biternata) were collected from the farmland of Chengdu Campus of Sichuan Agricultural 
University. Then, the seeds were put in the climate chamber to germinate and further cultivation and transplanting. The cultivar of grape is Kyoho with cutting seedlings. The fluvo-aquic soil samples were collected from the farmland at Chengdu Campus of Sichuan Agricultural University in April, 2016.

Experimental Design. The experiment was conducted in Chengdu Campus of Sichuan Agricultural University from April to July 2016. In April 2016, the soil was air-dried and passed through a $6.72-\mathrm{mm}$ sieve. $3 \mathrm{~kg}$ air-dried soil was weighed into each plastic pot $(21 \mathrm{~cm} \mathrm{high,} 20 \mathrm{~cm}$ in diameter), soaking uniformly by $5 \mathrm{mg} / \mathrm{kg} \mathrm{Cd}$ (in the form of $\mathrm{CdCl}_{2} \cdot 2.5 \mathrm{H}_{2} \mathrm{O}$ ) solution for 4 weeks. All pots were watered each day to keep the soil moisture about $80 \%$, and dug aperiodically to make soil mixed fully. In May 2016, three uniform-sized cutting seedlings (the shoots were about $15 \mathrm{~cm}$ ) of Kyoho grape were transplanted into each pot for monoculture and two of them for intercropping, respectively. One uniform-sized seedling (two pairs leaves expanded) of each Bidens species were transplanted into each pot for intercropping. The five treatments in experiment were monoculture of grape, grape intercropped with B. bipinnata, grape intercropped with $B$. pilosa, grape intercropped with $B$. parviflora and grape intercropped with $B$. biternata. For each treatment with three replicates and the pots placed completely random. The distance between pots was $15 \mathrm{~cm}$, and the pot position exchanged aperiodically to weaken the impact of the marginal effects. The soil moisture content was maintained at $80 \%$ of field capacity until the plants were harvested.

After 60 days, the grape seedlings were dug up and divided into three parts of root, stem, leaf, then washed with tap water firstly, followed by deionized water. After that, the organs of all plants were dried at $80{ }^{\circ} \mathrm{C}$ until constant weight, weighed, ground to $<0.149 \mathrm{~mm}$, and sealed into plastic bags for the determination of total $\mathrm{N}$, total $\mathrm{P}$ and total $\mathrm{K}$ contents [9]. The soil sample was collected, air-dried and ground to $<1.0 \mathrm{~mm}$ for analysis of alkali soluble $\mathrm{N}$, available $\mathrm{P}$ and available $\mathrm{K}$ concentrations [9].

Statistical Analyses. Statistical analyses were conducted using statistical software of SPSS 17.0. Data were analyzed by one-way ANOVA with least significant difference at $5 \%$ confidence level.

\section{Results and Discussion}

Total N Contents in Grape Seedlings. Compared with the monoculture, the total $\mathrm{N}$ contents in roots and shoots of grape seedlings decreased significantly $(p<0.05)$ by intercropping (Table 1$)$. The total $\mathrm{N}$ content in roots and shoots of grape seedlings were ranked as monoculture $>$ intercropping with $B$. Pilosa $>$ intercropping with B. Bipinnata $>$ intercropping with $B$. parviflora $>$ intercropping with $B$. Biternata. The results indicate that intercropping with Bidens species could not promote the $\mathrm{N}$ absorption of grape seedlings under Cd stress, which might be that the $\mathrm{N}$ compete ability of Bidens species is higher than grape seedlings.

Table 1 Total $\mathrm{N}$ contents in grape seedlings under Cd stress

\begin{tabular}{|l|l|l|l|c|}
\hline \multicolumn{1}{|c|}{ Treatments } & \multicolumn{1}{|c|}{$\begin{array}{c}\text { Roots } \\
(\mathrm{g} / \mathrm{kg})\end{array}$} & $\begin{array}{c}\text { Stems } \\
(\mathrm{g} / \mathrm{kg})\end{array}$ & $\begin{array}{c}\text { Leaves } \\
(\mathrm{g} / \mathrm{kg})\end{array}$ & $\begin{array}{c}\text { Shoots } \\
(\mathrm{g} / \mathrm{kg})\end{array}$ \\
\hline Monoculture & $9.89 \pm 0.21 \mathrm{a}$ & $3.70 \pm 0.15 \mathrm{a}$ & $14.52 \pm 0.40 \mathrm{a}$ & $11.07 \pm 0.27 \mathrm{a}$ \\
\hline Intercropping with B. bipinnata & $8.93 \pm 0.30 \mathrm{bc}$ & $3.59 \pm 0.16 \mathrm{a}$ & $13.74 \pm 0.34 \mathrm{bc}$ & $10.48 \pm 0.26 \mathrm{~b}$ \\
\hline Intercropping with B. pilosa & $9.19 \pm 0.28 \mathrm{~b}$ & $3.61 \pm 0.17 \mathrm{a}$ & $13.86 \pm 0.30 \mathrm{~b}$ & $10.55 \pm 0.23 \mathrm{~b}$ \\
\hline Intercropping with B. parviflora & $8.56 \pm 0.22 \mathrm{c}$ & $2.69 \pm 0.21 \mathrm{~b}$ & $13.34 \pm 0.32 \mathrm{bc}$ & $10.19 \pm 0.28 \mathrm{~b}$ \\
\hline Intercropping with B. biternata & $7.99 \pm 0.31 \mathrm{~d}$ & $2.55 \pm 0.24 \mathrm{~b}$ & $13.18 \pm 0.31 \mathrm{c}$ & $10.29 \pm 0.25 \mathrm{~b}$ \\
\hline
\end{tabular}

Values are means \pm standard errors. Means with the same letter within each column are not significantly different at $p<0.05$.

Total P Contents in Grape Seedlings. The total P content in roots of grape seedlings was ranked as intercropping with $B$. pilos $a>$ monoculture $>$ intercropping with $B$. bipinnata $>$ intercropping with B. parviflora $>$ intercropping with $B$. Biternata (Table 2). The total $\mathrm{P}$ content in shoots of grape seedlings increased by intercropping compared with the monoculture except intercropped with $B$. parviflora. When intercropped with $B$. pilosa, B. biternata and B. bipinnata, the total $\mathrm{P}$ content in 
shoots of grape seedlings increased by $20.00 \%(p<0.05), 10.00 \%(p<0.05)$ and $2.86 \%(p>0.05)$ respectively compared with the monoculture, indicating that intercropping with Bidens species could promote the $\mathrm{P}$ absorption of grape seedlings under Cd stress, and intercropping with $B$. pilosa could most effectively promote the $\mathrm{P}$ uptake in roots and shoots of grape seedlings.

Table 2 Total P contents in grape seedlings under Cd stress

\begin{tabular}{|l|l|c|c|c|}
\hline \multicolumn{1}{|c|}{ Treatments } & \multicolumn{1}{|c|}{$\begin{array}{c}\text { Roots } \\
(\mathrm{g} / \mathrm{kg})\end{array}$} & $\begin{array}{c}\text { Stems } \\
(\mathrm{g} / \mathrm{kg})\end{array}$ & $\begin{array}{c}\text { Leaves } \\
(\mathrm{g} / \mathrm{kg})\end{array}$ & $\begin{array}{c}\text { Shoots } \\
(\mathrm{g} / \mathrm{kg})\end{array}$ \\
\hline Monoculture & $1.30 \pm 0.02 \mathrm{ab}$ & $0.64 \pm 0.02 \mathrm{~b}$ & $0.73 \pm 0.01 \mathrm{c}$ & $0.70 \pm 0.01 \mathrm{c}$ \\
\hline Intercropping with B. bipinnata & $1.29 \pm 0.06 \mathrm{ab}$ & $0.56 \pm 0.04 \mathrm{c}$ & $0.80 \pm 0.03 \mathrm{~b}$ & $0.72 \pm 0.03 \mathrm{c}$ \\
\hline Intercropping with B. pilosa & $1.33 \pm 0.04 \mathrm{a}$ & $0.76 \pm 0.01 \mathrm{a}$ & $0.87 \pm 0.01 \mathrm{a}$ & $0.84 \pm 0.01 \mathrm{a}$ \\
\hline Intercropping with B. parviflora & $1.28 \pm 0.03 \mathrm{ab}$ & $0.58 \pm 0.03 \mathrm{c}$ & $0.69 \pm 0.02 \mathrm{~d}$ & $0.66 \pm 0.02 \mathrm{~d}$ \\
\hline Intercropping with B. biternata & $1.25 \pm 0.01 \mathrm{~b}$ & $0.74 \pm 0.01 \mathrm{a}$ & $0.79 \pm 0.02 \mathrm{~b}$ & $0.77 \pm 0.02 \mathrm{~b}$ \\
\hline
\end{tabular}

Values are means \pm standard errors. Means with the same letter within each column are not significantly different at $p<0.05$.

Total K Contents in Grape Seedlings. The total K contents in roots and shoots of grape seedlings decreased by intercropping compared with the monoculture (Table 3 ). When intercropped with $B$. bipinnata, B. pilosa, B. parviflora and B. biternata, the total $\mathrm{K}$ content in roots of grape seedlings decreased by $35.31 \%(p<0.05), 34.38 \%(p<0.05), 41.91 \%(p<0.05)$ and $39.66 \%(p<0.05)$ respectively, compared with the monoculture, and decreased by $18.78 \%(p<0.05), 7.62 \%(p>0.05)$, $19.78 \%(p<0.05)$ and $9.35 \%(p<0.05)$, respectively shoots of that. It indicates that intercropping with four Bidens species could inhibit the total $\mathrm{K}$ absorption of grape seedlings under $\mathrm{Cd}$ stress. Among the four Bidens species, intercropping with B. Pilosa made the least decrease of total K absorption of grape seedlings.

Table 3 Total $\mathrm{K}$ contents in grape seedlings under Cd stress

\begin{tabular}{|l|l|l|l|l|}
\hline \multicolumn{1}{|c|}{ Treatments } & \multicolumn{1}{|c|}{$\begin{array}{c}\text { Roots } \\
(\mathrm{g} / \mathrm{kg})\end{array}$} & $\begin{array}{c}\text { Stems } \\
(\mathrm{g} / \mathrm{kg})\end{array}$ & $\begin{array}{c}\text { Leaves } \\
(\mathrm{g} / \mathrm{kg})\end{array}$ & \multicolumn{1}{c|}{$\begin{array}{c}\text { Shoots } \\
(\mathrm{g} / \mathrm{kg})\end{array}$} \\
\hline Monoculture & $20.45 \pm 0.43 \mathrm{a}$ & $9.53 \pm 0.32 \mathrm{a}$ & $11.71 \pm 0.44 \mathrm{a}$ & $11.02 \pm 0.39 \mathrm{a}$ \\
\hline Intercropping with B. bipinnata & $13.23 \pm 0.46 \mathrm{~b}$ & $7.12 \pm 0.67 \mathrm{c}$ & $9.82 \pm 0.58 \mathrm{~b}$ & $8.95 \pm 0.61 \mathrm{c}$ \\
\hline Intercropping with B. pilosa & $13.42 \pm 0.60 \mathrm{~b}$ & $9.24 \pm 0.10 \mathrm{a}$ & $10.52 \pm 0.87 \mathrm{~b}$ & $10.18 \pm 0.62 \mathrm{ab}$ \\
\hline Intercropping with B. parviflora & $11.88 \pm 0.23 \mathrm{c}$ & $7.27 \pm 0.28 \mathrm{c}$ & $9.50 \pm 0.43 \mathrm{~b}$ & $8.84 \pm 0.38 \mathrm{c}$ \\
\hline Intercropping with B. biternata & $12.34 \pm 0.44 \mathrm{bc}$ & $8.29 \pm 0.36 \mathrm{~b}$ & $10.61 \pm 0.45 \mathrm{~b}$ & $9.99 \pm 0.41 \mathrm{~b}$ \\
\hline
\end{tabular}

Values are means \pm standard errors. Means with the same letter within each column are not significantly different at $p<0.05$.

Soil Alkali Soluble N, Available P and Available K Concentrations. The changes of soil alkali soluble $\mathrm{N}$, available $\mathrm{P}$ and available $\mathrm{K}$ concentrations got a significant level $(p<0.05)$ by intercropping compared with the monoculture (Table 4). The soil alkali soluble $\mathrm{N}$ concentration of intercropping significantly increased compared with the monoculture. When grape seedlings intercropped with B. bipinnata, B. pilosa, B. parviflora and B. biternata, the soil alkali soluble N concentration increased by $8.29 \%, 16.79 \%, 11.69 \%$ and $11.91 \%$ respectively compared with the monoculture. The soil available $\mathrm{P}$ and available $\mathrm{K}$ concentrations of intercropping decreased compared to monoculture. When grape seedlings intercropped with B. bipinnata, B. pilosa, B. parviflora and $B$. biternata, the soil available $\mathrm{P}$ concentration decreased by $16.99 \%, 11.38 \%, 20.74 \%$ and $15.13 \%$ respectively, compared with the monoculture, and the soil available $\mathrm{K}$ concentration decreased by $36.76 \%, 19.58 \%, 39.48 \%$ and $28.31 \%$, respectively. These results indicate that intercropping could improve the soil alkali soluble $\mathrm{N}$ concentration, but not improve the soil available $\mathrm{P}$ and available $\mathrm{K}$ concentrations. The treatment of grape seedlings intercropped with $B$. pilosa could maximally improve the soil alkali soluble $\mathrm{N}$ concentration and make the soil available $\mathrm{P}$ and available $\mathrm{K}$ concentrations reduce least. 
Table 4 Soil alkali soluble $\mathrm{N}$, available $\mathrm{P}$ and available $\mathrm{K}$ concentrations

\begin{tabular}{|c|c|c|c|}
\hline Treatments & $\begin{array}{c}\text { Alkali soluble N } \\
(\mathrm{mg} / \mathrm{kg})\end{array}$ & $\begin{array}{c}\text { Available P } \\
(\mathrm{mg} / \mathrm{kg})\end{array}$ & $\begin{array}{c}\text { Available K } \\
(\mathrm{mg} / \mathrm{kg})\end{array}$ \\
\hline Grape monoculture & $111.38 \pm 5.80 \mathrm{c}$ & $30.66 \pm 0.55 \mathrm{a}$ & $105.37 \pm 2.03 \mathrm{a}$ \\
\hline Grape intercropped with B. bipinnata & $120.61 \pm 1.20 \mathrm{~b}$ & $25.45 \pm 1.21 \mathrm{bc}$ & $66.64 \pm 1.67 \mathrm{~d}$ \\
\hline Grape intercropped with B. pilosa & $130.08 \pm 4.04 \mathrm{a}$ & $27.17 \pm 1.90 \mathrm{~b}$ & $84.74 \pm 2.16 \mathrm{~b}$ \\
\hline Grape intercropped with B. parviflora & $124.40 \pm 4.12 \mathrm{ab}$ & $24.30 \pm 1.15 \mathrm{c}$ & $63.77 \pm 4.21 \mathrm{~d}$ \\
\hline Grape intercropped with B. biternata & $124.65 \pm 3.08 \mathrm{ab}$ & $26.02 \pm 1.66 \mathrm{bc}$ & $75.54 \pm 0.60 \mathrm{c}$ \\
\hline
\end{tabular}

Values are means \pm standard errors. Means with the same letter within each column are not significantly different at $p<0.05$.

\section{Conclusions}

When grape seedlings intercropped with four Bidens species, the total $\mathrm{N}$ and total $\mathrm{K}$ contents in grape seedlings decreased compared with the monoculture. Intercropping decreased the total $\mathrm{P}$ content in roots of grape seedlings except intercropping with $B$. pilos $a$ and increased the total $\mathrm{P}$ content in shoots of grape seedlings except intercropping with $B$. parviflora. Compared with the monoculture, the soil available $\mathrm{P}$ and available $\mathrm{K}$ concentrations of intercropping decreased, but the soil alkali soluble $\mathrm{N}$ concentration of intercropping significantly increased. On the whole, intercropping with $B$. pilosa could most effectively improve the $\mathrm{P}$ absorption of grape seedlings and inhibit the $\mathrm{N}$ and $\mathrm{K}$ absorption of that. Therefore, intercropping with B. pilosa could benefit the nutrient absorption of grape seedlings under Cd stress.

\section{Acknowledgements}

This work was financially supported by the Application Infrastructure Project of Science and Technology Department of Sichuan Province (2016JY0258).

\section{References}

[1] L. Li, X.L. Li, F.S. Zhang, J.H. Sun, S.C. Yang and M.J. Lu: Plant Nutrition and Fertilizer Science Vol. 6 (2000), p. 140.

[2] H.K. Li, G.J. Zhang, Z.Y. Zhao and K.R. Li: Acta Horticulturae Sinica Vol. 34 (2007), p. 477.

[3] Y.S. He, J.Z. Weng, R.M. Li and W.J. Wu: Subtropical Agriculture Research Vol. 1 (2005), p. 45.

[4] Y.Z. Fan: Jiangsu Agricultural Science Vol. 39 (2011), p. 482.

[5] C.J. Li, W. Ma, and F.S. Zhang: Plant Nutrition and Fertilizer Science Vol. 14 (2008), p. 178.

[6] S.H. Wei, C.J. Yang and Q.X. Zhou: Environmental Science Vol. 29 (2008), p. 2912.

[7] L.L. Dong, X.G. Zhao, S.J. Zhang, Y.H. Zhang, N. Liang and Y.M. Zhao: Chinese Journal of Soil Science Vol. 40 (2009), p. 374.

[8] Y.B. Sun, Q.X. Zhou, L. Wang, W.T. Liu and R. Liu: Environmental Science Vol. 30 (2009), p. 3028.

[9] S.D. Bao: Agrochemical Soil Analysis (3rd edition, China Agriculture Press, Beijing, China 2000). 